Board of Governors of the Federal Reserve System

\author{
International Finance Discussion Papers
}

Number 825

January 2005
Expansionary Fiscal Shocks and the Trade Deficit
Christopher J. Erceg
Luca Guerrieri
Christopher Gust

NOTE: International Finance Discussion Papers are preliminary materials circulated to stimulate discussion and critical comment. References in publications to International Finance Discussion Papers (other than an acknowledgement that the writer has had access to unpublished material) should be cleared with the author or authors. Recent IFDPs are available on the Web at www.federalreserve.gov/pubs/ifdp/. 


\title{
Expansionary Fiscal Shocks and the Trade Deficit*
}

\author{
Christopher J. Erceg, Luca Guerrieri**, and Christopher Gust
}

\begin{abstract}
In this paper, we use an open economy DGE model (SIGMA) to assess the quantitative effects of fiscal shocks on the trade balance in the United States. We examine the effects of two alternative fiscal shocks: a rise in government consumption, and a reduction in the labor income tax rate. Our salient finding is that a fiscal deficit has a relatively small effect on the U.S. trade balance, irrespective of whether the source is a spending increase or tax cut. In our benchmark calibration, we find that a rise in the fiscal deficit of one percentage point of GDP induces the trade balance to deteriorate by less than 0.2 percentage point of GDP. Noticeably larger effects are only likely to be elicited under implausibly high values of the short-run trade price elasticity.
\end{abstract}

Keywords: DGE model, open-economy macroeconomics

JEL Codes: F32, F41, E62

* We thank Matthieu Bussière and Paolo Pesenti as well as seminar participants at the Federal Reserve Board, George Washington University, the Council on Foreign Relations, and the International Monetary Fund. The views expressed in this paper are solely the responsibility of the authors and should not be interpreted as reflecting the views of the Board of Governors of the Federal Reserve System or of any other person associated with the Federal Reserve System.

** Corresponding Author: Luca Guerrieri, Telephone 202-452-2550, Fax 202-872-4926. Email addresses: christopher.erceg@frb.gov, luca.guerrieri@frb.gov, and christopher.j.gust@frb.gov. 


\section{Introduction}

After a decade of relative inattention, there is renewed interest in assessing the relationship between fiscal policy and trade deficits. This interest has been fuelled by the steady increase in the U.S. trade deficit to over 5 percent of GDP in early 2004, and the more recent swing in the U.S. fiscal balance from surplus to a large deficit (see Figure 1).

Some economists and policymakers believe that fiscal deficits have played a fairly minor role in accounting for the increase in the trade deficit, and instead have attributed the U.S. trade balance deterioration to other factors. A proponent of this view is U.S. Treasury Undersecretary John Taylor (2004):

The increase of the U.S. current account deficit over more than a decade has been linked to domestic U.S. capital formation increasing more than U.S. saving. Perceived high rates of return on U.S. assets, based on strong productivity growth relative to the rest of the world, combined with an efficient and secure U.S. capital market attracts foreign investment.

By contrast, others have argued that fiscal deficits play a central role in explaining both the persistence and recent expansion of the trade deficit. For example, Bradford DeLong (2004) has observed that:

We have a large trade deficit now - and did not back in 1997, [...] because (a) the federal government budget deficit is much larger now than it was then, and (b) private savings declined as a share of GDP during the bubble years of the late 1990s, and has not fully recovered.

It does not seem feasible to discriminate between these alternative views based on a simple examination of the joint evolution of the fiscal and trade balances. As seen in Figure 1, the fiscal deficits of the 1980s and early part of this decade were indeed associated with a pronounced deterioration of the trade balance. However, the fiscal and trade balances frequently have moved in opposite directions, perhaps reflecting an endogenous component of the fiscal balance, and that other factors have played a significant role in driving the trade balance. Thus, methods more 
sophisticated than "eyeball econometrics" are required to isolate the effects of fiscal policy changes on the trade balance.

In this context, it is natural to turn to the empirical literature to help assess the linkage between fiscal policy and the trade deficit. Unfortunately, the literature appears to offer widely divergent estimates, and there is even disagreement about the sign of the effect of a fiscal deficit on the trade balance. For example, Roubini (1988) and Normandin (1999) found that government budget deficits induced a fairly substantial deterioration in the trade deficit, with the latter estimating that a one dollar increase in the fiscal deficit of the United States resulted in an increase in the external deficit between $\$ 0.22$ and $\$ 0.98$. By contrast, Evans (1988) and Bussière et al (2004) concluded that the fiscal deficits only have a small effect on the current account, and Roubini and Kim (2003) reported the surprising finding based on structural VAR analysis that expansionary fiscal shocks tend to improve the current account.

In this paper, we take an alternative approach by using an open economy DGE model to assess the quantitative effect of fiscal shocks on the trade balance. Our model is a slightly modified version of a new micro-founded multi-country model named "SIGMA" that we have developed in the International Finance Division of the Federal Reserve Board. ${ }^{1}$ Our model builds on the framework of the workhorse new Keynesian model by incorporating many of the key nominal and real frictions that have been identified in the recent literature as playing an important role in accounting for the effects of both real and monetary shocks. Our model also introduces heterogeneity across households by assuming that some households simply consume their after-tax disposable income each period; such non-Ricardian behavior has important implications for fiscal policy.

We examine the effects of two alternative fiscal shocks, including a rise in gov-

\footnotetext{
${ }^{1}$ Here we limit our attention to two countries, and focus exclusively on tax shocks. For a more detailed discussion of the SIGMA model and its properties, see Erceg, Guerrieri, and Gust (2004).
} 
ernment consumption, and a reduction in the labor income tax rate. As shown in Figure 2, both higher government spending and tax reductions have contributed to the large swing in the fiscal balance from surplus to substantial deficit during the past few years.

Our salient finding is that fiscal shocks have relatively small effects on the trade balance under reasonable calibrations of our model to the U.S. economy. In our benchmark calibration, we find that a one percentage point rise in the government spending share of GDP induces the trade balance/GDP ratio to deteriorate by less than 0.2 percentage point after $2-3$ years (where the effect reaches a maximum). The small effect reflects that the pressure on the external sector associated with higher fiscal spending is largely alleviated through a rise in output, and by a contraction in private domestic absorption due to higher real interest rates and a negative wealth effect. Moreover, a labor tax rate cut that is scaled to induce a deterioration of the fiscal balance of about 1 percentage point of GDP (about the same as the government spending shock) also generates a trade balance deterioration of less than 0.2 percentage point of GDP.

Our small estimates of the effects of fiscal shocks on trade may appear surprising. Some previous work using micro-founded open economy models reported considerably larger effects; for instance, Baxter (1995) found that a one percentage point rise in the government spending/GDP share caused a trade balance deterioration equal to about 0.5 percentage point of GDP. We show that the primary difference between our analysis and this earlier work is that our baseline calibration implies a much lower short-run price elasticity of export and import demand. We corroborate that a higher trade price elasticity indeed makes the trade balance more responsive, since a higher elasticity shifts more of the adjustment towards net exports; however, we argue that short-run trade price elasticities would have to be implausibly high to yield substantially larger effects than in our benchmark calibration. The longrun price elasticity of 1.5 for exports and imports that we use in our benchmark 
calibration may in fact exaggerate the trade response, as it is at the upper end of estimates in the macro-literature.

We conduct sensitivity analysis on several other dimensions, including to the interest sensitivity of consumption and investment spending, the form of the monetary policy rule, the share of non-Ricardian households in the economy, and the persistence of the shocks. We find that our estimates of the impact of the fiscal shocks on trade are fairly insensitive to the interest-sensitivity of the demand components, and to the form of the monetary policy rule. Moreover, we argue that our baseline calibration if anything tends to exaggerate the effects of fiscal shocks on the trade balance through our assumptions that non-Ricardian agents comprise 50 percent of households.

We also confront the question of whether our benchmark model offers an empirically realistic framework for assessing the effects of fiscal policy shocks. While our model's implications for the evolution of output, consumption and investment are qualitatively consistent with the structural VAR evidence reported by Blanchard and Perotti (2002), our benchmark model implies significantly more rapid adjustment of output and the expenditure components. Accordingly, we consider an alternative information structure in which agents have incomplete information about the persistence of the government spending shock. This framework allows our model to come much closer to matching the highly persistent responses of output and the expenditure components derived from the empirical VAR analysis, and also from large-scale policy models in which expectations are formed adaptively. ${ }^{2}$ Interestingly, the effects of a government spending shock on the trade balance under imperfect information are somewhat smaller than in our benchmark calibration with full information.

Applying our framework to the current situation, our analysis suggests that

\footnotetext{
${ }^{2}$ In the paper, we compare our model's implications with those of the FRB/Global model, a workhorse model used for policy simulations at the Federal Reserve.
} 
while stimulative fiscal policy has probably contributed to the large and widening U.S. trade deficit, its quantitative role has been modest. Even assuming that the structural U.S. government deficit has deteriorated by 5 percentage points of GDP due to spending increases and tax cuts - and thus making the rather extreme assumption that most of the swing in the fiscal position is due to policy shocks - our estimates would suggest that such stimulus would generate a trade deficit of less than 1 percent of GDP. This suggests that most of the U.S. trade deficit has been driven by factors other than the fiscal expansion, including possibly shifts in portfolio preferences towards U.S. assets, and the continued strength in labor productivity growth.

The remainder of this paper is organized as follows. Section 2 presents our basic open economy model. The calibration is discussed in Section 3. Section 4 reports our simulation results. Section 5 concludes.

\section{The Model}

Our model consists of two countries that differ in size, but are otherwise isomorphic. Hence, our exposition below focuses on the "home" country. Each country in effect produces a single domestic output good, although we adopt a standard monopolistically competitive framework to rationalize stickiness in the aggregate price level. While household utility depends on consumption of both the domestic output good and imported goods, it is convenient to assume that a competitive distribution sector purchases both inputs, and simply resells a final consumption good to households. Similarly, we assume that competitive distributors combine the domestic output good with imports to produce a final investment good.

To introduce non-Ricardian consumption behavior, we assume that there are two types of households in each country. "Optimizing" households maximize welfare subject to an intertemporal budget constraint. These households own the entire 
capital stock, accumulate capital subject to adjustment costs and exhibit habit persistence in their consumption decisions. They also are regarded as monopolistic competitors in the labor market in order to account for aggregate wage stickiness. The other type of households ("rule of thumb" households) simply consume their entire after-tax disposable income.

\subsection{Firms and Price Setting}

\section{Production of Domestic Intermediate Goods.}

There is a continuum of monopolistically competitive firms in the home country (indexed by $i \in[0,1]$ ), each of which produces a differentiated intermediate good. As in Betts and Devereux (1996), intermediate goods producers set prices in advance in the buyer's currency and thus may charge different prices at home and abroad (i.e., they practice local currency pricing). In the home market, firm $i$ faces a demand function that varies inversely with its output price $P_{D t}(i)$ and directly with aggregate demand at home $Y_{D t}$ :

$$
Y_{D t}(i)=\left[\frac{P_{D t}(i)}{P_{D t}}\right]^{\frac{-\left(1+\theta_{p}\right)}{\theta_{p}}} Y_{D t},
$$

where $\theta_{p}>0$, and $P_{D t}$ is an aggregate price index defined below. Similarly, in the foreign market, firm $i$ faces the demand function:

$$
X_{t}(i)=\left[\frac{P_{M t}^{*}(i)}{P_{M t}^{*}}\right]^{\frac{-\left(1+\theta_{p}\right)}{\theta_{p}}} M_{t}^{*},
$$

where $P_{M t}^{*}(i)$ denotes the price that firm $i$ sets in the foreign market (denominated in foreign currency), while $P_{M t}^{*}$ is the foreign import price index, and $M_{t}^{*}$ is aggregate foreign imports (we use an asterisk to denote foreign variables).

Each producer utilizes capital services $K_{t}(i)$ and a labor index $L_{t}(i)$ (defined below) to produce its respective output good. The production function is assumed to have a constant-elasticity of substitution (CES) form:

$$
Y_{t}(i)=\left(\omega_{K}^{\frac{\rho}{1+\rho}} K_{t}(i)^{\frac{1}{1+\rho}}+\omega_{L}^{\frac{\rho}{1+\rho}}\left(Z_{t} L_{t}(i)\right)^{\frac{1}{1+\rho}}\right)^{1+\rho} .
$$


The production function exhibits constant-returns-to-scale in both inputs, and $Z_{t}$ is a deterministic trend in the level of technology that grows at the same rate $g_{z}$ in both countries. Firms face perfectly competitive factor markets for hiring capital and the labor index. Thus, each firm chooses $K_{t}(i)$ and $L_{t}(i)$, taking as given both the rental price of capital $R_{K t}$ and the aggregate wage index $W_{t}$ (defined below). Firms can costlessly adjust either factor of production. Thus, the standard static first-order conditions for cost minimization imply that all firms have identical marginal cost per unit of output, $M C_{t}$.

We assume that the home and foreign prices of the intermediate goods are determined by Calvo-style staggered contracts (see Calvo 1983). In each period, a firm faces a constant probability, $1-\xi_{p}$, of being able to reoptimize its price at home $\left(P_{D t}(i)\right)$ and $1-\xi_{p, x}$ probability of being able to reoptimize its price abroad $\left(P_{M t}^{*}(i)\right)$. These probabilities are assumed to be independent across firms, time, and countries. If a firm is not allowed to reoptimize its prices, we follow Christiano, Eichenbaum, and Evans (2001) and assume the firm resets its home price based on lagged aggregate inflation. Prices are updated according to $P_{D t}(i)=\pi_{t-1} P_{D t-1}(i)$ where $\pi_{t}=P_{D t} / P_{D t-1} \cdot{ }^{3}$ Similarly, in foreign markets, if a firm can not reoptimize its price, the price is changed according to the rule, $P_{M t}^{*}(i)=\pi_{M t-1}^{*} P_{M t-1}^{*}(i)$ where $\pi_{M t}^{*}=P_{M t}^{*} / P_{M t-1}^{*}$. This form of lagged indexation is a mechanism for introducing inflation inertia into the key price-setting equations.

When a firm is allowed to reoptimize its price in the domestic market in period $t$, the firm maximizes

$$
\widetilde{\mathbb{E}}_{t} \sum_{j=0}^{\infty} \xi_{p}^{j} \psi_{t, t+j}\left[V_{D t+j} P_{D t}(i) Y_{D t+j}(i)-M C_{t+j} Y_{D t+j}(i)\right] .
$$

The operator $\widetilde{\mathbb{E}}_{t}$ represents the conditional expectation based the information avail-

\footnotetext{
${ }^{3}$ In alternative calibrations of SIGMA, we also consider the specification used by Yun (1995) and Erceg, Henderson, and Levin (2000) where $P_{D t}(i)=\pi P_{D t-1}(i)$ so that $V_{D t+j}=\pi^{j}$ in the profit functional defined below; similarly, prices are updated according to $P_{M t}(i)=\pi^{*} P_{M t-1}(i)$ in foreign markets. Given this form of static indexing, the price-setting equation is purely forward-looking, so that there is no intrinsic inflation inertia.
} 
able to agents at period $t$. The firm discounts profits received at date $t+j$ by the state-contingent discount factor $\psi_{t, t+j}$; for notational simplicity, we have suppressed all of the state indices. ${ }^{4}$ Also, $V_{D t+j}$ is defined by

$$
V_{D t+j}=\prod_{h=1}^{j} \pi_{t+h-1} .
$$

We define a separate profit functional for a firm's optimal choice of its price in the foreign market at date $t$, that mimics equation (4).

Production of the Domestic Output Index.

Because households have identical Dixit-Stiglitz preferences, it is convenient to assume that a representative aggregator combines the differentiated intermediate products into an aggregate for home-produced goods $Y_{D t}$ :

$$
Y_{D t}=\left[\int_{0}^{1} Y_{D t}(i)^{\frac{1}{1+\theta_{p}}} d i\right]^{1+\theta_{p}} .
$$

The aggregator chooses the bundle of goods that minimizes the cost of producing $Y_{D t}$, taking the price $P_{D t}(i)$ of each intermediate good $Y_{D t}(i)$ as given. The aggregator is also a price-taker in the output market and sells its output at $P_{D t}$, which can be regarded as the aggregate price index for the domestically-produced good. Similarly, an aggregator combines the differentiated import goods into a composite import index, $M_{t}$, which it sells at a price, $P_{M t}$.

\section{Production of Consumption and Investment Goods.}

Final consumption goods are produced by a representative "consumption good distributor." This firm combines purchases of the domestically-produced composite good with the composite imported good to produce a final consumption good $\left(C_{t}\right)$ according to a constant-returns-to-scale CES production function:

\footnotetext{
${ }^{4}$ We define $\xi_{t, t+j}$ to be the price in period $t$ of a claim that pays one dollar if the specified state occurs in period $t+j$ (see the household problem below); then the corresponding element of $\psi_{t, t+j}$ equals $\xi_{t, t+j}$ divided by the probability that the specified state will occur.
} 


$$
C_{t}=\left(\omega_{C}^{\frac{\rho_{C}}{1+\rho_{C}}} C_{D t}^{\frac{1}{1+\rho_{C}}}+\left(1-\omega_{C}\right)^{\frac{\rho_{C}}{1+\rho_{C}}}\left(\varphi_{C t} M_{C t}\right)^{\frac{1}{1+\rho_{C}}}\right)^{1+\rho_{C}}
$$

where $M_{C t}$ is an index of imported goods, and $\varphi_{C t}$ reflects costs of adjusting consumption imports. The quasi-share parameter $\omega_{C t}$ may be interpreted as determining the degree of home bias in household consumption expenditure. The adjustment cost term $\varphi_{C t}$ is assumed to take the quadratic form:

$$
\varphi_{C t}=\left[1-\frac{\varphi_{M_{C}}}{2}\left(\frac{\frac{M_{C t}}{C_{D t}}}{\frac{M_{C t-1}}{C_{D t-1}}}-1\right)^{2}\right]
$$

This specification implies that it is costly to change the share of the imported good in total consumption.

Given the presence of adjustment costs, the representative consumption goods distributor chooses (a contingency plan for) $C_{D t}$ and $M_{C t}$ to minimize its discounted expected costs of producing the aggregate consumption good:

$$
\begin{aligned}
& \min _{C_{D t}, M_{C t}} \widetilde{\mathbb{E}}_{t} \sum_{k=0}^{\infty} \psi_{t, t+k}\left\{\left(P_{D t+k} C_{D t+k}+P_{M t+k} M_{C t+k}\right)\right. \\
& \left.+P_{C t+k}\left[C_{t+k}-\left(\omega_{C}^{\frac{\rho_{C}}{1+\rho_{C}}} C_{D t+k}^{\frac{1}{1+\rho_{C}}}+\left(1-\omega_{C}\right)^{\frac{\rho_{C}}{1+\rho_{C}}}\left(\varphi_{C t+k} M_{C t+k}\right)^{\frac{1}{1+\rho_{C}}}\right)^{1+\rho_{C}}\right]\right\} .
\end{aligned}
$$

The distributor sells the final consumption good to households at a price $P_{C t}$, which may be interpreted as the consumption price index (or equivalently, as the shadow cost of producing an additional unit of the consumption good).

We model the production of final investment goods in an analogous manner. We allow for costs $\varphi_{I t}$ that reflect costs of adjusting imports of investment goods and for a degree of home bias that may differ from that in the consumption aggregator. Investment goods distributors solve an intertemporal cost minimization problem isomorphic to that of consumption goods distributors. The distributor sells the final investment good to households at a price of $P_{I t}$. 


\section{$2.2 \quad$ Households and Wage Setting}

We assume a continuum of households (indexed on the unit interval), each of which supplies a differentiated labor service to the intermediate goods-producing sector (the only producers demanding labor services in our framework). It is convenient to assume that a representative labor aggregator (or "employment agency") combines households' labor hours in the same proportions as firms would choose. Thus, the aggregator's demand for each household's labor is equal to the sum of firms' demands. The aggregate labor index $L_{t}$ has the Dixit-Stiglitz form:

$$
L_{t}=\left[\int_{0}^{1}\left(\zeta N_{t}(h)\right)^{\frac{1}{1+\theta_{w}}} d h\right]^{1+\theta_{w}}
$$

where $\theta_{w}>0$ and $N_{t}(h)$ is hours worked by a typical member of household $h$. Also, $\zeta$ is the size of a household of type $h$ and determines the size of the population. The aggregator minimizes the cost of producing a given amount of the aggregate labor index, taking each household's wage rate $W_{t}(h)$ as given, and then sells units of the labor index to the production sector at their unit cost $W_{t}$ :

$$
W_{t}=\left[\int_{0}^{1} W_{t}(h)^{-\frac{1}{\theta_{w}}} d h\right]^{-\theta_{w}} .
$$

It is natural to interpret $W_{t}$ as the aggregate wage index. The aggregator's demand for the labor services of a typical member of household $h$ is given by

$$
N_{t}(h)=\left[\frac{W_{t}(h)}{W_{t}}\right]^{-\frac{1+\theta_{w}}{\theta_{w}}} L_{t} .
$$

The utility functional of a typical member of household $h$ is

$$
\begin{aligned}
& \widetilde{\mathbb{E}}_{t} \sum_{j=0}^{\infty} \beta^{j}\left\{\frac{1}{1-\sigma}\left(C_{t+j}(h)-\varkappa C_{t+j-1}\right)^{1-\sigma}+\right. \\
& \left.\frac{\chi_{0} Z_{t}^{1-\sigma}}{1-\chi}\left(1-N_{t+j}(h)\right)^{1-\chi}+\frac{\mu_{0}}{1-\mu}\left(\frac{M B_{t+j+1}(h)}{P_{C t+j}}\right)^{1-\mu}\right\},
\end{aligned}
$$

where the discount factor $\beta$ satisfies $0<\beta<1$. As in Smets and Wouters (2003), we allow for the possibility of external habits, where an individual in the household cares 
about his consumption relative to lagged aggregate consumption per capita $\left(C_{t}\right)$. The period utility function depends on current leisure $1-N_{t}(h)$ and an individual's end-of-period real money balances, $\frac{M B_{t+1}(h)}{P_{C t}}$. We allow for a deterministic shift in preferences over leisure so that the model is consistent with balanced growth, even if the subutility function over consumption is not logarithmic $(\sigma \neq 1)$.

We assume that there are two types of households: households that make intertemporal consumption, labor supply, and capital accumulation decisions in a forward-looking manner by maximizing utility subject to an intertemporal budget constraint (optimizing households); and rule-of-thumb (RT) households that simply consume their after-tax disposable income, and choose to set their wage to be the average wage of optimizing households. The latter type of households receive no capital rental income or profits. We denote the fixed share of optimizing households by $\varsigma .{ }^{5}$

We consider first the problem faced by optimizing households. Each member of household $h$ faces a flow budget constraint which states that his combined expenditure on goods and on the net accumulation of financial assets must equal his disposable income:

$$
\begin{gathered}
P_{C t} C_{t}(h)+P_{I t} I_{t}(h)+M B_{t+1}(h)-M B_{t}(h)+\int_{s} \xi_{t, t+1} B_{D t+1}(h) \\
-B_{D t}(h)+P_{B t} B_{G t+1}-B_{G t}+\frac{e_{t} P_{B t}^{*} B_{F t+1}(h)}{\phi_{b t}}-e_{t} B_{F t}(h) \\
=\left(1-\tau_{N t}\right) W_{t}(h) N_{t}(h)+\Gamma_{t}(h)+T R_{t}(h)-T_{t}(h)+\left(1-\tau_{K}\right) R_{K t} K_{t}(h)+ \\
\tau_{K} \delta P_{I t} K_{t}(h)-P_{D t} \phi_{I t}(h) .
\end{gathered}
$$

\footnotetext{
${ }^{5}$ Mankiw (2000) stresses the importance of including rule of thumb behavior in models for analyzing fiscal policy. Mankiw cites estimates suggesting that consumption smoothing is far from perfect and that many households have net worth near zero. Galí, López-Salido, and Vallés also incorporate rule-of-thumb households into their model to account for a rise in aggregate consumption in response to a government spending shock.
} 
Final consumption goods are purchased at a price $P_{C t}$, and final investment goods at a price $P_{I t}$. Investment in physical capital augments the (end-of-period) capital stock $K_{t+1}(h)$ according to a linear transition law of the form:

$$
K_{t+1}(h)=(1-\delta) K_{t}(h)+I_{t}(h) .
$$

Financial asset accumulation of a typical member of an optimizing household $h$ consists of increases in nominal money holdings $\left(M B_{t+1}(h)-M B_{t}(h)\right)$ and the net acquisition of bonds. We assume that agents within a country can engage in frictionless trading of a complete set of contingent claims, while trade in international assets is restricted to a non-state contingent nominal bond. The term $P_{B t} B_{G t+1}-B_{G t}$ represents net purchases of domestic government bonds, while $\int_{s} \xi_{t, t+1} B_{D t+1}(h)-B_{D t}(h)$ are net purchases of state-contingent domestic bonds. We denote $\xi_{t, t+1}$ as the price of an asset that will pay one unit of domestic currency in a particular state of nature at date $t+1$, while $B_{D t+1}(h)$ represents the quantity of such claims purchased by a member of household $h$ at time $t$. Thus, the gross outlay on new state-contingent domestic claims is given by integrating over all states at time $t+1$, while $B_{D t}(h)$ indicates the value of existing claims given the realized state of nature.

In equation (14), $B_{F t+1}(h)$ represents the quantity of a non-state contingent bond purchased at time t that pays one unit of foreign currency in the subsequent period, $P_{B t}^{*}$ is the foreign currency price of the bond, and $e_{t}$ is the exchange rate expressed in units of home currency per unit of foreign currency. We follow Benigno (2001) and assume there is an intermediation cost $\phi_{b t}$ paid by households in the home country for purchases of foreign bonds, which ensures that net foreign assets are stationary in the model. ${ }^{6}$

Each member of an optimizing household $h$ earns after-tax labor income, $(1-$

\footnotetext{
${ }^{6}$ This intermediation cost is asymmetric, as foreign households do not face these costs. Rather, they collect profits on the monopoly rents associated with these intermediation costs. The intermediation costs depend on the ratio of economy-wide holdings of net foreign assets to nominal output and are given by: $\phi_{b t}=\exp \left(-\phi_{b}\left(\frac{e_{t} B_{F t+1}}{P_{D t} Y_{t}}\right)\right)$.
} 
$\left.\tau_{N t}\right) W_{t}(h) N_{t}(h)$, where $\tau_{N t}$ is a stochastic tax on labor income. The household leases capital to firms at the after-tax rental rate $\left(1-\tau_{K}\right) R_{K t}$, where $\tau_{K}$ is a tax on capital income. The household receives a depreciation writeoff of $\tau_{K} P_{I t} \delta$ per unit of capital (where $\delta$ is the depreciation rate of capital). Each member also receives an aliquot share $\Gamma_{t}(h)$ of the profits of all firms and a government lump-sum transfer $T R_{t}(h)$, and pays a lump-sum tax $T_{t}(h)$.

We allow for costs associated with adjusting the capital stock. As in Christiano, Eichenbaum, and Evans (2001), it is costly to change the level of gross investment from the previous period, so that the acceleration in the capital stock is penalized:

$$
\phi_{I t}(h)=\frac{1}{2} \phi_{I} \frac{\left(I_{t}(h)-I_{t-1}(h)\right)^{2}}{I_{t-1}(h)} .
$$

In every period $t$, each member of an optimizing household $h$ maximizes the utility functional (13) with respect to its consumption, investment, (end-of-period) capital stock, money balances, holdings of contingent claims, and holdings of domestic and foreign bonds, subject to its labor demand function (12), budget constraint (14), and transition equation for capital (15). In doing so, a household takes as given prices, taxes, transfers, and aggregate quantities such as lagged aggregate per capita consumption and the aggregate net foreign asset position.

Optimizing households set nominal wages in staggered contracts that are analogous to the price contracts described above. In particular, with probability $1-\xi_{w}$, each member of a household is allowed to reoptimize his wage contract. If a household is not allowed to optimize its wage rate, we assume each household member must reset his price according to:

$$
W_{t}(h)=\omega_{t-1} W_{t-1}(h),
$$

where $\omega_{t}=W_{t} / W_{t-1}$ and in steady state $\omega=\pi g_{z}$. Each member of household $h$ chooses the value of $W_{t}(h)$ to maximize his utility functional (13).

Finally, we consider the determination of consumption and labor supply of the rule-of-thumb (RT) households. These households simply equate their nominal con- 
sumption spending to their current after-tax disposable income, which consists of labor income plus net lump-sum transfers from the government:

$$
P_{C t} C_{t}(h)=\left(1-\tau_{N t}\right) W_{t}(h) N_{t}(h)+T R_{t}-T_{t}(h)
$$

The RT households set their wage to be the average wage of the optimizing households. Since RT households face the same labor demand schedule as the optimizing households, each RT household works the same number of hours as the average for optimizing households.

\subsection{Monetary Policy}

We assume that the central bank follows an interest rate reaction function similar in form to the historical rule estimated by Orphanides and Wieland (1998) over the Volcker-Greenspan period. Thus, the short-term nominal interest rate is adjusted so that the ex post real interest rate rises when inflation exceeds its constant target value, or when output growth rises above some target value. With some allowance for interest rate smoothing, monetary policy is described by the following interest rate reaction function:

$$
i_{t}=\gamma_{i} i_{t-1}+\bar{r}+\bar{\pi}+\gamma_{\pi}\left(\pi_{t}^{(4)}-\bar{\pi}\right)+\gamma_{y}\left(y_{t}-y_{t-1}-g_{z}\right) .
$$

In the above, $i_{t}$ is the annualized nominal interest rate, $\pi_{t}^{(4)}$ is the four-quarter

inflation rate of domestically-produced goods (i.e., $\pi_{t}^{(4)}=\sum_{j=0}^{3} \pi_{t-j}$ ), $\bar{r}$ and $\bar{\pi}$ are the steady-state real interest rate and the central bank's constant inflation target (both expressed at annual rate). Also, $y_{t}-y_{t-1}$ is the (annualized) quarterly growth rate of total output.

\subsection{Fiscal Policy}

Some of the domestically-produced good is purchased by the government. Government purchases $\left(G_{t}\right)$ are assumed to have no direct effect on the utility of a 
household. ${ }^{7}$ We also assume that government purchases as a fraction of total output, $g_{t}=G_{t} / Y_{t}$, follow an exogenous stochastic process.

The government can issue debt $B_{G t+1}$ to finance a deficit so that its budget constraint is given by:

$$
\begin{gathered}
P_{B t} B_{G t+1}-B_{G t}=P_{D t} G_{t}+T R_{t}-T_{t}-\tau_{N t} W_{t} L_{t}+\tau_{K}\left(R_{K t}-\delta P_{I t}\right) K_{t} \\
-\left(M B_{t+1}-M B_{t}\right) .
\end{gathered}
$$

In equation (20) all variables are in per-capita terms.

Capital tax rates and real transfer rates (defined as $\frac{T R_{t}}{P_{D t} Y_{t}}$ ) are held constant. Given that the monetary authority uses the nominal interest rate as its policy instrument, the level of seignorage revenues are determined by nominal money demand.

Lump-sum taxes are adjusted in a manner that the government satisfies an intertemporal solvency constraint, requiring that the present discounted value of the government debt stock tends toward zero in the long run. In particular, we assume that the real lump-sum tax rate, $\tau_{t}=\frac{T_{t}}{P_{D t} Y_{t}}$, is determined according to the following reaction function:

$$
\tau_{t}=\tau_{t-1}+\nu_{1}\left(b_{G t+1}-b_{G}\right)+\nu_{2}\left(b_{G t+1}-b_{G t}\right),
$$

where $b_{G t+1}=\frac{B_{G t+1}}{P_{t} Y_{t}}$ and $b_{G}$ is the government's target value for the ratio of government debt to nominal output.

Government purchases as a fraction of total output, $g_{t}$ evolve according to a first-order autoregressive process:

$$
g_{t}=\rho_{g} g_{t-1}+\epsilon_{g t},
$$

where $\epsilon_{g t}$ is an identically and independently distributed innovation. Similarly, the

\footnotetext{
${ }^{7}$ We could assume instead that government purchases enter separably in the utility function. This would not alter the model's equilibrium outcome but would have different welfare consequences.
} 
labor tax rate, $\tau_{N t}$, evolves according to a first-order autoregression with persistence parameter $\rho_{N}$.

\subsection{Resource Constraint and Net Foreign Assets}

The home economy's aggregate resource constraint can be written as:

$$
Y_{t}=C_{D t}+I_{D t}+G_{t}+M_{t}^{*}+\phi_{I t},
$$

where $M_{t}^{*}=M_{C t}^{*}+M_{I t}^{*}$, and $\phi_{I t}$ is the adjustment cost on investment.

The evolution of net foreign assets is derived from the budget constraint of the optimizing households after imposing the government budget constraint, the consumption rule of the RT households, the definition of firm profits, and the condition that domestic bonds are in zero net supply.

Finally, we assume that the structure of the foreign economy (the "rest of the world") is isomorphic to that of the home country.

\section{Solution Method and Calibration}

We solve the model by log-linearizing the equations around the steady state. To obtain the reduced-form solution of the model, we use the numerical algorithm of Anderson and Moore (1985), which provides an efficient implementation of the method proposed by Blanchard and Kahn (1980) (see also Anderson (1997)). ${ }^{8}$

The model is calibrated at a quarterly frequency. Structural parameters are set at identical values for each of the two countries, except for the parameters determining population size (as discussed below).

The utility functional parameter $\sigma$ is set equal to 2, while the parameter determining the degree of habit persistence in consumption $\varkappa=0.8$. We assume that the

\footnotetext{
${ }^{8}$ We evaluated the robustness of our solution procedure by using a nonlinear Newton-Raphson algorithm that does not rely on linearization around an initial steady state, and found that the results were nearly identical to those reported.
} 
discount factor $\beta=0.997$ and $g_{z}=1.0037$, which is consistent with a steady-state annualized real interest rate $\bar{r}$ of roughly 4 percent and trend output growth of about $1.5 \%$ per year. We set $\chi=10$, implying a Frisch elasticity of labor supply of $1 / 5$, which is considerably lower than if preferences were logarithmic in leisure, but well within the range of most empirical estimates. The utility parameter $\chi_{0}$ is set so that employment comprises one-third of the household's time endowment, while the parameter $\mu_{0}$ on the subutility function for real balances is set to an arbitrarily low value (so that variation in real balances has a negligible impact on other variables). Following Campbell and Mankiw (1989), we choose $\varsigma=0.5$ so that 50 percent of households are optimizing agents and the rest are RT agents. ${ }^{9}$

The depreciation rate of capital $\delta=.025$ (consistent with an annual depreciation rate of 10 percent). The wage markup parameter $\theta_{w}=0.10$, reasonably similar to the value estimated by Amato and Laubach (1999) of 0.13 (the price markup parameter $\theta_{p}$ has no effect on the linearized dynamics). We set $\xi_{p}$ and $\xi_{w}$ to be consistent with four-quarter contracts (subject to full indexation). The parameter $\xi_{p, x}$ is chosen to be consistent with two-quarter contracts, so that the pass-through of exchange rate changes to import prices occurs relatively quickly. ${ }^{10}$ We set the steady state inflation rate $\pi$ to yield an annual inflation rate of four percent.

The parameter $\rho$ in the CES production function of the intermediate goods producers is set to -2 , implying an elasticity of substitution between capital and labor of $1 / 2$. Thus, capital and labor are less substitutable than the unitary elasticity case implied by the Cobb-Douglas specification. The quasi-capital share parameter $\omega_{K}$ is chosen to imply a steady state investment to output ratio of 16 percent. The private

\footnotetext{
${ }^{9}$ Our calibrated share is on the high range of estimates surveyed by Weber (2002). As indicated below, a smaller share would imply that fiscal deficits induce an even smaller deterioration in the trade balance than under our benchmark parameterization.

${ }^{10}$ The rapid adjustment of import prices is consistent with the evidence Campa and Goldberg (2004) derived from a panel of OECD countries, nothwithstanding their finding that long-run passthrough is generally well below 100 percent for OECD countries.
} 
consumption to output ratio is 66 percent, while government consumption is 18 percent of steady state output. We set the cost of adjusting investment parameter $\phi_{I}=4$, close to value used by Christiano, Eichenbaum, and Evans (2001).

The parameter $\omega_{C}$ is chosen to match the estimated average share of imports in total U.S. consumption of about 9 percent (according to NIPA data for the 19952003 period); while the parameter $\omega_{I}$ is chosen to match the average share of imports in total U.S. investment of about 38 percent. Given that trade is balanced in steady state, this parameterization implies an import or export to GDP ratio for the home country (the United States) of about 12 percent. We choose population levels $\zeta$ and $\zeta^{*}$ so that the home country constitutes about 25 percent of world output. This implied an import (or export) share of output of the foreign country of about 4 percent.

We assume that $\rho_{C}=\rho_{I}=2$, consistent with a long-run price elasticity of demand for imported consumption and investment goods of 1.5. This estimate is towards the higher end of estimates derived using macroeconomic data, which are typically in the range of unity; nevertheless, this voluminous literature has produced a wide range of estimates, with the upper bound in the vicinity of $3 .^{11}$ We set the adjustment cost parameter $\varphi_{M_{C}}=\varphi_{M_{I}}=10$, implying a price-elasticity of slightly less than unity after four quarters. ${ }^{12}$ We choose a small value (0.0001) for the financial intermediation cost $\phi_{b}$, which is necessary to ensure the model has a unique steady state.

\footnotetext{
${ }^{11}$ While it is unsurprising that the vast empirical literature estimating trade price elasticities has reported a range of estimates, the level of aggregation used in estimation seems of crucial importance. Estimates of the long-run elasticity derived from aggregate data are typically in the range of unity, e.g., Hooper and Marquez (1995), with the estimate of an import price elasticity of 3.5 of Erkel, Rousse, and Mirza (2004) a clear outlier. By contrast, estimates using disaggregated data are frequently in the range of 3 or even higher; see Obstfeld and Rogoff (2001) for a concise review or McDaniel and Balistreri (2003) for a more detailed survey.

${ }^{12}$ Hooper, Johnson and Marquez (2000) find that the short-run elasticity is significantly smaller than the long-run elasticity in their study using macroeconomic data. This is qualitatively consistent with the results of industry studies as surveyed by McDaniel and Balistreri (2003).
} 
We estimated the parameters of the monetary policy rule using U.S. data from 1983:1-2003:4. ${ }^{13}$ Our estimates implied $\gamma_{\pi}=0.6, \gamma_{y}=0.28$, and $\gamma_{i}=0.8$. For the tax rate reaction function, we choose $\nu_{1}=0.001, \nu_{2}=0.01$, and $b_{G}=0$. We set the steady state capital and labor tax rates equal to 0.3 and 0.2 , respectively.

\section{Rise in Government Spending Share}

Figure 3 shows the effects of an exogenous rise in the U.S. government spending share of GDP of one percentage point. Given the high persistence of the shock $\left(\rho_{g}=.975\right)$, the government spending share still remains about 0.6 percentage point above steady state after five years (lower right panel). Initially, the primary government budget deficit rises about 0.8 percentage point. ${ }^{14}$ The deficit is still 0.4 percentage point higher than the baseline level five years after the shock, reflecting that lump-sum tax rates increase very gradually given our parametrization of the tax-rate reaction function. While it may seem unrealistic to assume that government purchases can be financed solely through adjusting lump-sum taxes, our results for the trade balance would be nearly unchanged if we instead assumed slow adjustment of the labor tax rate.

The rise in government spending induces an immediate expansion of output. The government spending multiplier exceeds unity in the impact period of the shock due to the sharp rise in consumption of the rule-of-thumb (RT) households. However, rising real interest rates quickly crowd out private investment and the consumption of the interest-sensitive optimizing households; the consumption of the latter is depressed further because of the negative wealth effect of higher government spending. Thus, overall private consumption falls below baseline after only a few quarters, and most of the output expansion is reversed. The small but more persistent component

\footnotetext{
${ }^{13}$ We estimated the rule using instrumental variables with lags of inflation and output growth as instruments.

${ }^{14}$ The deficit-to-GDP ratio rises by less than 1 percentage point due to an endogenous rise in government receipts from taxes on labor and capital income.
} 
of the output increase reflects a rise in labor supply that is induced by the negative wealth effect.

It is interesting to note that the responses of GDP, consumption, and investment are broadly consistent with the empirical VAR evidence of Blanchard and Perotti (2002). These authors find that after a government spending shock, consumption and GDP rise, while investment falls. The peak responses of these variables from their VAR estimates are reasonably in line with those in Figure 3. For example, their point estimates for the peak response of the government spending output multiplier range from 0.9 to 1.3 in alternative specifications, slightly smaller than the 1.5 percent peak response in our model. However, the VAR evidence suggests that the responses of GDP and consumption are more persistent than in our benchmark specification.

We next consider the effects of the government spending shock on the external sector, which is the primary focus of our analysis. Because higher real interest rates induce an appreciation of the real exchange rate (shown by a movement downwards in Figure 3), the relative price of imported goods falls, while the price of exports rises in foreign markets. ${ }^{15}$ These relative price changes boost real import demand and reduce export demand, though the response to price changes is moderated in the short-run by adjustment costs. The positive effect on imports due to the relative price change is partly offset by a decline in private consumption and investment spending.

Accordingly, the quantitative magnitude of the responses of real exports and real imports depend crucially on i) the magnitude of real exchange rate appreciation, ii) the price elasticities of export and import demand, and iii) on factors that determine the response of private consumption and investment spending. In our benchmark calibration, our assumptions about the degree of substitutability between home and

\footnotetext{
${ }^{15}$ The effect of the change in the exchange rate on import and export prices is muted initially given our assumption of local currency pricing; however, exchange rate passthrough is nearly complete after a few quarters.
} 
foreign goods imply that the price elasticities of export and import demand are each about 1 after a year and 1.5 in the long-run (which is nearly attained after 2 years). Given that the relative price of imports in the foreign country rises about 1 percent after 2 years (essentially the reverse of the response of home import prices shown in the upper right panel of Figure 3), exports fall about 1-1/2 percent. Real imports rise by a somewhat more modest amount, because the relative price effect is partly offset by a contraction in consumption and investment.

The nominal trade/GDP ratio deteriorates by about 0.15 percentage point relative to baseline after about two years. Interestingly, nominal imports/GDP actually decline slightly, since the rise in real imports is more than offset by the fall in their relative price. Given that the export price converges to the price of domesticallyproduced goods after a few quarters, almost all of the deterioration in the nominal trade balance turns out to be attributable to a fall in real exports. ${ }^{16}$

Finally, it is also helpful to consider trade adjustment from the saving-investment perspective embodied in the national accounts identity:

$$
\frac{T B_{t}}{P_{t}}=\left(Y_{t}-\frac{P_{C t}}{P_{t}} C_{t}-\frac{N T_{t}}{P_{t}}\right)+\left(\frac{N T_{t}}{P_{t}}-G_{t}\right)-\frac{P_{I t}}{P_{t}} I_{t}
$$

where $T B_{t}$ is the nominal trade balance, $P_{t}$ is the GDP deflator, and $N T_{t}$ denotes taxes net of transfers. This relation expresses the real trade balance as the sum of real private and public saving (the first and second terms in parentheses, respectively), minus real investment. ${ }^{17}$ Ceteris paribus, a rise in government spending would induce government saving and the real trade balance to deteriorate by a corresponding amount. However, in our model this aggregate demand pressure on the external balance is largely offset by a rise in private saving (as output rises and consumption eventually contracts), and by a fall in investment spending. The output

\footnotetext{
${ }^{16}$ Given that exports fall 1-1/2 percent and the steady state export/GDP ratio is 0.12 , the partial effect on the nominal trade/GDP ratio is a 0.18 percentage point decline.

${ }^{17}$ Because we assume adjustment costs on investment, the national accounts identity in equation (24) only holds to a first-order approximation in our model.
} 
expansion, consumption decline, and investment decline all play important roles in alleviating the pressure on the external balance due to the government spending hike.

\subsection{Sensitivity Analysis}

We have shown that government spending shocks have quite modest effects on the trade balance in our benchmark calibration. In this section we consider the sensitivity of this result to the price elasticity of import/export demand, the interest rate sensitivity of consumption and investment, the persistence of the shocks, the fraction of RT agents, the monetary policy rule, and the information structure. This analysis is helpful in comparing our estimates of the effects on trade of government spending shocks with those of the related literature.

While the parameter $\rho_{C}$ in equation (7) determines the long-run trade price elasticity $\left(\frac{1+\rho_{C}}{\rho_{C}}\right)$, the parameter $\varphi_{M C}$ in equation (8) influences the short-run trade price elasticity. Costs of adjustment on trade effectively lower the short-run trade price elasticity below the long-run level. Figure 4 compares the responses to a government consumption shock under our benchmark calibration (the solid blue line), and under two alternative calibrations. The first (the dashed green line) increases the long-run trade price elasticity to 3 without varying the parameter determining adjustment costs in trade; this implies that the trade elasticity after four quarters is about 1.5, rather than slightly below unity as in our baseline. ${ }^{18}$ The second variant (the dash-dotted red line) sets the adjustment cost parameter to zero, so that the trade price elasticity is 3 in the impact period of the shock.

Increasing the trade elasticity stimulates greater substitution towards imports in the domestic market, and a larger fall in domestic exports, even allowing for a smaller real appreciation of the domestic currency. Nevertheless, it is interesting

\footnotetext{
${ }^{18}$ As noted in the calibration section, this choice of a long-run trade price elasticity is at the upper bound of estimates derived from macro data.
} 
that the magnitude of nominal trade balance deterioration only rises to about 0.25 percentage point of GDP in the first alternative, even though the implied dynamic path of the trade price elasticity is much higher than typically estimated using macro data.

As shown in the second variant, our model is capable of generating large trade responses similar in magnitude to those derived in the open economy RBC literature (as Baxter 1995); thus, with the short-run elasticity equal to 3, the government spending shock induces the trade balance/GDP ratio to deteriorate by about $1 / 2$ percentage point. However, short-run trade elasticities of this magnitude seem implausibly high. Moreover, in interpreting these results, it is important to keep in mind that our model implies nearly full exchange rate pass-through to import prices after a few quarters. In the more plausible case of incomplete pass-through, the same trade price elasticities would generate considerably smaller effects on the trade balance.

Figure 5 considers the effects of varying model parameters that influence the short-run interest sensitivity of private domestic absorption. In our first alternative (denoted by the dashed green line), we decreased the inter-temporal elasticity of substitution in consumption by raising $\sigma$ in equation (13) from 2 to 3, and also markedly increased investment adjustment costs. With a lower interest-sensitivity of private absorption, domestic interest rates increase by a larger amount (not shown), inducing a larger initial appreciation of the real exchange rate: thus, more of the burden of adjustment to the government spending shock is shifted to the external sector. ${ }^{19}$ Nevertheless, even though our alternative calibration would imply shortrun interest rate elasticities at the low end of the macroeconomic literature, the trade balance only deteriorates about 0.2 percentage point of GDP, only slightly more than in the benchmark calibration. Conversely, Figure 5 shows that with

\footnotetext{
${ }^{19}$ However, this effect is partially offset by the effect of higher real rates on private domestic absorption, as the policy rule acts to choke off higher growth in nominal demand.
} 
a logarithmic subutility function over consumption and relatively low investment adjustment costs, the trade balance only deteriorates about 0.1 percentage point of GDP.

Figure 6 examines the effects of varying the persistence of government consumption shocks. In our model, less persistent government spending shocks induce a less persistent rise in the real interest rate, which causes a smaller real exchange rate appreciation and hence a smaller deterioration of the trade balance. Thus, as illustrated by the dashed green line, the same one percent rise in the government spending share only induces a trade balance deterioration of about $1 / 20$ percentage point of GDP when the autocorrelation coefficient of the shock is reduced to 0.5; moreover, as shown in a second alternative, the maximum trade balance deterioration would only approach that in our benchmark parameterization if there were no adjustment costs in trade.

The dashed green line in Figure 7 shows the response to a persistent government consumption shock when all households choose their consumption path by optimizing their utility function. In this case, domestic consumption falls on impact, which accounts for the negative response of private absorption. Accordingly, the real exchange rate does not appreciate as much as under the benchmark parametrization (the solid blue line), inducing a more modest deterioration of the trade balance than in the benchmark case. ${ }^{20}$ Figure 7 also suggests that our results are not particularly sensitive to the choice of a monetary policy rule. The responses generated by adopting a Taylor rule are almost indistinguishable from those in our benchmark case. $^{21}$

Finally, we consider a case in which agents have imperfect information about

\footnotetext{
${ }^{20}$ In a DGE model that assumes all households are optimizers, Müller (2004) shows that a lower import price elasticity of substitution than used here could even lead to an improvement in the trade balance following a rise in government spending. Under these conditions, our model could also generate an improvement.

${ }^{21}$ The Taylor rule we used has a coefficient of 1.5 on the four-quarter change in domestic inflation and 0.5 on the output gap, where potential output is determined by holding employment at its steady state level.
} 
whether the shock to government consumption is highly persistent or transitory. As noted above, our benchmark model implies significantly more rapid adjustment of output and the expenditure components to a fiscal expansion than is implied by estimates from structural VARs, or by large-scale policy models such as the FRB/Global model (see Levin et al. 1997, for a description of this model). Accordingly, we introduce an "information friction" as a mechanism for eliciting more gradual responses, and to help evaluate whether such changes in model structure have important implications for the response of the trade balance.

More specifically, we assume that while agents can observe the current shock to government consumption, they are unsure whether the shock is to the highly persistent component (which has an autocorrelation parameter of 0.975 , as in the benchmark), or to the transitory component (which has an autocorrelation parameter of 0.5, as in the alternative cases in Figure 6). Accordingly, agents solve a signal extraction problem by using the Kalman filter.

Figure 8 compares the case with imperfect information (the dash-dotted green line) with the benchmark case. Because agents initially perceive that the increase in government spending is temporary under imperfect information, there is a larger increase in GDP in this case than in the benchmark. Furthermore, the rise in GDP is more persistent, as agents only slowly update their beliefs about the persistence of the shock and are continually surprised by the higher-than-expected levels of government spending. Interestingly, this version of our model comes closer than the benchmark to matching the gradual response of output (dashed red line) and private absorption implied by the FRB/Global model to the same shock.

Given that agents expect the government spending rise to die out more quickly under imperfect information, there is less pressure on the exchange rate to appreciate, and correspondingly, a smaller deterioration of the trade balance. Importantly, a rise in private saving plays a key role in offsetting the pressure on the external balance under either information structure, with the subtle difference that a rise in 
output rather than a fall in consumption plays a relatively larger role in accounting for the private saving expansion under imperfect information.

\subsection{A Reduction in Labor Taxes}

As shown in Figure 2, reductions in personal taxes have played an even larger role than government spending hikes in accounting for the recent deterioration in the fiscal deficit; moreover, most of the tax declines due to policy changes reflect successive reductions in tax rates on labor income. Accordingly, it is of interest to consider whether fiscal deficits induced by labor tax cuts have effects on the trade balance that are broadly comparable with those of government spending shocks.

Figure 9 shows the effects of a cut in labor tax rates that is scaled so that labor taxes would fall by one percentage point of GDP if pre-tax labor income and output were unaffected. The shock is assumed to be highly persistent, with the autoregressive parameter $\rho_{N}$ set to 0.975 . This labor tax cut induces the fiscal deficit to follow nearly the same path as in the case of the government spending rise considered in Figure 3, with the initial fiscal deficit of nearly 1 percent of GDP falling to around $1 / 2$ percent after 5 years. As above, we assume that lump-sum taxes are raised very gradually to bring the government debt/GDP level back to its target level. ${ }^{22}$

The cut in labor taxes induces a sharp rise in output. The initial rise in output reflects that the RT households immediately increase their consumption as their after-tax income expands. The high level of persistence of aggregate consumption reflects that the consumption of the RT households remains high for an extended duration (given that the cut to labor taxes is very persistent, and lump-sum taxes adjust slowly). Output declines from its initial peak as rising real interest rates crowd out investment spending and the consumption of optimizing households; however,

\footnotetext{
${ }^{22}$ We verified that the implications for the trade deficit reported below would be virtually unaffected if we assumed instead that the endogenous tax adjustment occurred through a gradual increase in labor tax rates.
} 
output remains persistently above its pre-shock level because lower tax rates induce households to work more by raising the cost of leisure.

The channel through which the labor tax cut affects the external sector is broadly similar to the case of the government spending shock. In particular, higher real interest rates induce the real exchange rate to appreciate, which reduces the relative price of imports at home, and boosts it abroad. These relative price movements generate a decline in real exports, and a rise in imports. The associated deterioration of the nominal trade balance of about 0.12 percentage point of GDP is only slightly smaller than the decline in the case of the government spending shock; the smaller decline in the former case reflects that the labor supply shock stimulates output in the longer-term, which dampens the initial appreciation of the real exchange rate. ${ }^{23}$

The quantitative effects of the labor tax cut on the trade balance are slightly augmented under an alternative calibration that imposes a higher Frisch elasticity of labor supply. Figure 10 compares the effects of the tax cut under the benchmark calibration in which the Frisch elasticity is 0.2 with an alternative in which the Frisch elasticity is set equal to unity. The latter value is much higher than estimates from most microeconomic studies, but has frequently been utilized in the RBC literature. It is clear that the response of output and domestic absorption is much larger with a high labor supply elasticity, reflecting that more substitution into work induces a higher demand for capital, and directly boosts output. However, the quantitative effect on the trade balance is only slightly larger than in our benchmark case. While a greater surge in investment demand has the partial effect of stimulating import demand by more, the larger supply-side effects of the shock dampen the initial appreciation of the exchange rate.

Figure 10 also shows the implications of assuming that all agents are optimizers.

\footnotetext{
${ }^{23}$ The positive supply side effects of the labor tax cut dampen the magnitude of the real interest rate increase, and also cause the real exchange rate to depreciate in the longer-term; given the uncovered interest parity condition, these effects serve to dampen the initial appreciation relative to the case of the goverment spending shock.
} 
Interestingly, the effect of the labor tax cut on the trade balance under this alternative are virtually nil. In the absence of RT households, there is much less upward pressure on real interest rates, so that the real exchange rate exhibits a slight initial depreciation. Thus, the size of the trade balance deterioration in our benchmark is even more sensitive to our assumption about the share of RT households than in the case of the government spending shock.

As in the case of the government spending shock, the magnitude of the effects of the labor tax cut on the trade balance also depend on the trade price elasticity. However, for an economy with structural characteristics such as the United States, implausibly high trade price elasticities would be required to elicit trade balance deteriorations significantly larger than in our benchmark case. For example, even with a long-run trade price elasticity of 6 (consistent with an elasticity of 2 after four quarters), the trade balance would only deteriorate by 0.2 percentage point of GDP. We regard this estimate as a firm upper bound on the impact of a labor tax cut of the magnitude considered, because sensible modifications to our model structure, such as a lower share of RT households or incomplete exchange rate pass-through, would be likely to reduce the effects we are reporting.

\section{Conclusions}

Our model-based analysis suggests that changes in fiscal policy have fairly small effects on the U.S. trade balance, irrespective of whether the source is a spending increase or tax cut: in our benchmark calibration, a rise in the fiscal deficit of one percentage point of GDP causes the trade balance to deteriorate by less than 0.2 percentage point. Most of the pressure on the external balance due to expansionary fiscal policy is offset by a combination of higher output, and/or a fall in private consumption and investment.

From a policy perspective, our results suggest putting little credence in the idea 
that fiscal policy changes are likely to exert sizeable effects on the U.S. trade balance. Accordingly, fiscal contraction in the United States is unlikely to be instrumental in narrowing the burgeoning U.S. trade deficit, even if it might be desirable on other grounds. 


\section{References}

Amato, J.D., Laubach, T., 2003. Estimation and Control of an Optimization-Based Model with Sticky Prices and Wages. Journal of Economic Dynamics and Control $27,1181-1215$.

Anderson, G.S., 1997. A Reliable and Computationally Efficient Algorithm for Imposing the Saddle Point Property in Dynamic Models.Occasional Staff Studies 4, Board of Governors of the Federal Reserve System.

Anderson, G.S., Moore, G., 1985. A linear algebraic procedure for solving linear perfect foresight models. Economic Letters 17, 247-252.

Baxter, M., 1995. International Trade and Business Cycles, in: Grossmann, G.M., Rogoff, K., eds., Handbook of International Economics, Vol. 3, pp. 1801-1864. North Holland, Amsterdam.

Benigno, P., 2001. Price Stability with Imperfect Financial Integration. CEPR discussion paper no. 2854 .

Betts, C. and M.B. Devereux, 1996. The Exchange Rate in a Model of Pricing to Market. European Economic Review, Vol. 40, iss. 3-5, pp. 1007-21.

Betts, C. and M.B. Devereux, 1999. The International Effects of Monetary and Fiscal Policy in a Two-Country Model. Discussion paper no. 99-10, University of British Columbia.

Blanchard, O., Kahn, C., 1980. The Solution of Linear Difference Models under Rational Expectations. Econometrica 48, 1305-1311.

Blanchard, O. and Perotti, 2002. An Empirical Characterization of the Dynamic Effects of Changes in Government Spending and Taxes on Output. Quarterly Journal of Economics, Vol 117, 4, 1329-1368. 
Botman, D., Laxton, D. and Romanov, A., 2004. A New Open Economy Macro Model for Fiscal Policy Evaluation. Manuscript, International Monetary Fund.

Bussière, M., Fratzscher, M., Müller, G., 2004. Productivity Shocks, Budget Deficits and the Current Account. Manuscript, European Central Bank.

Calvo, G., 1983. Staggered Prices in a Utility Maximizing Framework. Journal of Monetary Economics 12, 383-98.

Campa, J.M., Golberg, L. 2004. Exchange Rate Pass-Through into Import Prices. CEPR discussion paper no 4391.

Campbell, J.Y., Mankiw, N.G., 1989. Consumption, Income an Interest Rates: Reinterpreting the Time Series Evidence. In Blanchard, O.J., Fischer, S. (Eds.), NBER Macroeconomics Annual. MIT Press, Cambridge, MA, 185-214.

Christiano, L., Eichenbaum, M., Evans, C., 2001. Nominal Rigidities and the Dynamic Effects of a Shock to Monetary Policy, National Bureau of Economic Research Working Paper 8403.

DeLong, B., 2004. John Taylor Blasts Off for the Gamma Quadrant, in Brad DeLong's Semi-Daily Journal: A Weblog. Downloaded from http://www.j-bradforddelong.net/movable_type/2004-2_archives/000519.html

Erceg, C., Guerrieri, L. and Gust, C., 2004. SIGMA, a New Open Economy Model for Policy Analysis. Manuscript, Board of Governors of the Federal Reserve System.

Erceg, C., Henderson, D., Levin, A., 2000. Optimal Monetary Policy with Staggered Wage and Price Contracts. Journal of Monetary Economics 46, 281-313.

Evans, P., 1990. Do Budget Deficits Affect the Current Account. Manuscript, Ohio State University. 
Galí, J., López-Salido, D., Vallés, J., 2003. Understanding the Effects of Government Spending on Consumption. Bank of Spain, working paper no. 0321.

Gallaway, M.P., McDaniel, C.A., Rivera, S.A., 2000. Short-Run and Long-Run Industry-Level Estimates of U.S. Armington Elasticities. North American Journal of Economics and Finance, forthcoming.

Hooper, P., Marquez, J., 1995. Exchange Rates, Prices, and External Adjustment in the United States and Japan. In Kenen, P. (ed) Understanding Independence, Princeton University Press, Princeton N.J., 1995, 107-68.

Hooper, P., Johnson, K. and Marquez, J. 2000. Trade Elasticities for the G-7 Countries. Princeton Studies in International Economics, 87.

Levin, A. T., Rogers, J. H. and Tryon, R. W., 1997. A Guide to FRB/Global. Board of Governors of the Federal Reserve Systerm, International Finance Discussion Paper No. 588.

Müller, G. 2004. Understanding the Dynamic Effects of Government Spending on Foreign Trade. Mimeo, European University Institute.

Mankiw, N. G., 2000. The Savers-Spenders Theory of Fiscal Policy, NBER working paper no. 7571.

McDaniel, C., Balistreri, E., 2003. A Review of Armington Trade Substitution Elasticities. Integration and Trade Journal, Vol. 7, iss. 18, 161-73.

Normandin, M., 1999. Budget Deficit Persistence and the Twin Deficits Hypothesis. Journal of International Economics, 49, 171-193.

Obstfeld, M. and Rogoff, K., 2001. The Six Major Puzzles in International Economics. In Bernanke, B. S. and Rogoff K. (eds) NBER Macroeconomics Annual 2000. MIT Press: Cambridge, 339-90. 
Orphanides, A., Wieland, V., 1998. Price stability and monetary policy effectiveness when nominal interest rates are bounded at zero. Board of Governors of the Federal Reserve System (U.S.), Finance and Economics Discussion Series no. 1998-35.

Roubini N., 1988. Current Account and Budget Deficits in an Intertemporal Model of Consumption and Taxation Smoothing. A Solution to the "Feldstein-Horioka Puzzle". NBER working paper no. 2773.

Roubini N., and Kim, S., 2003. Twin Deficit or Divergence? Fiscal Policy, Current Account, and Real Exchange Rate in the US. Manuscript, New York University.

Frank Smets, F. and Wouters, R. (2003). An Estimated Dynamic Stochastic General Equilibrium Model of the Euro Area. Journal of the European Economic Association, Vol. 1, 1124-1175.

Taylor, J. B. (2004). The U.S. Current Account: Recent Trends and Policies, U.S. Treasury Office of Public Affairs, JS 2084.

Weber, C.E., 2002. Intertemporal non-separability and "rule of thumb" consumption. Journal of Monetary Economics, Vol. 49, iss. 2, 293-308.

Yun, T., 1996. Nominal Price Rigidity, Money Supply Endogeneity, and Business Cycles. Journal of Monetary Economics 37, 345-370. 
Figure 1: The U.S. Fiscal and Trade Balances as a share of GDP

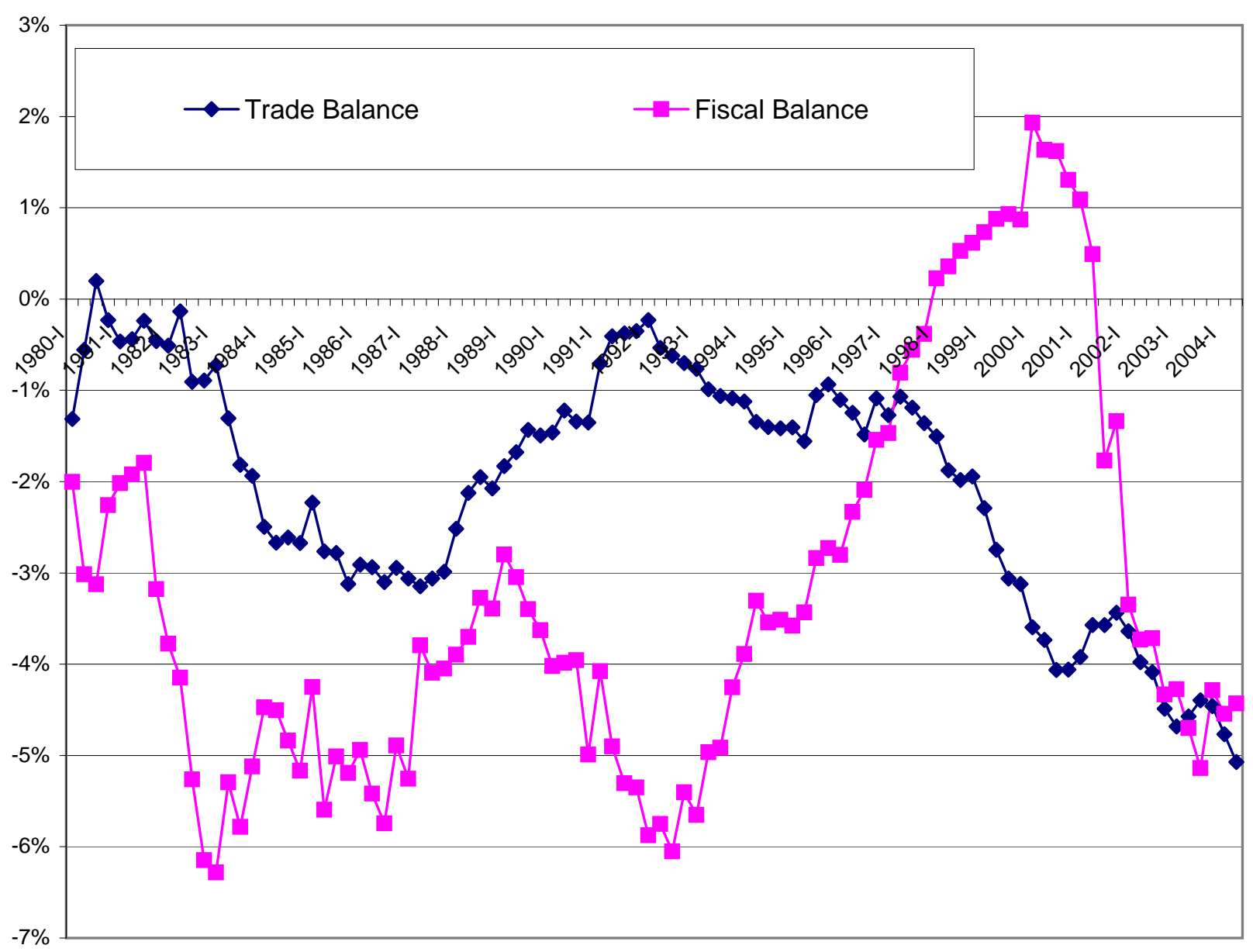

Source: NIPA 
Figure 2: Selected Government Expenditures and Revenues as a share of GDP

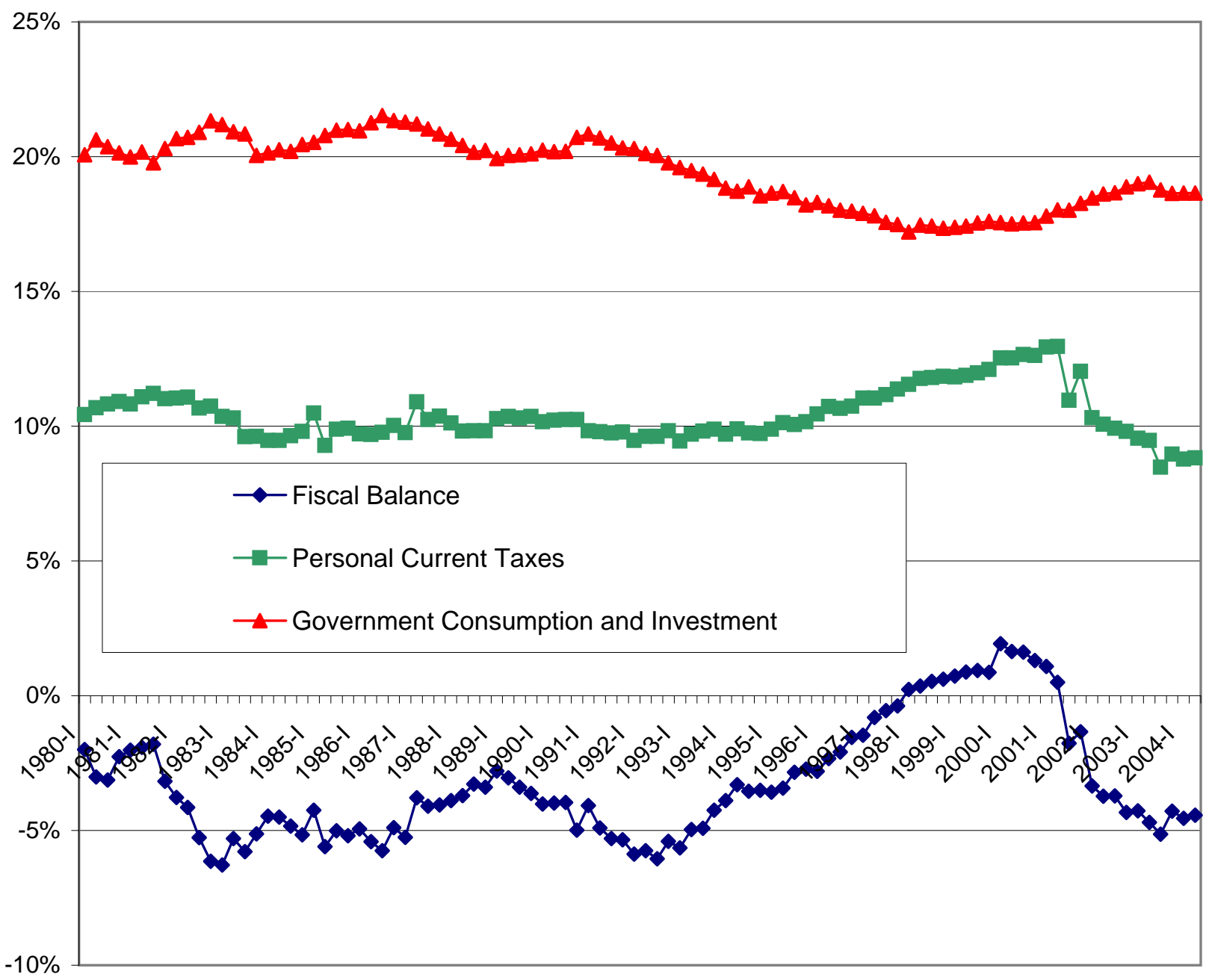

Source: NIPA 

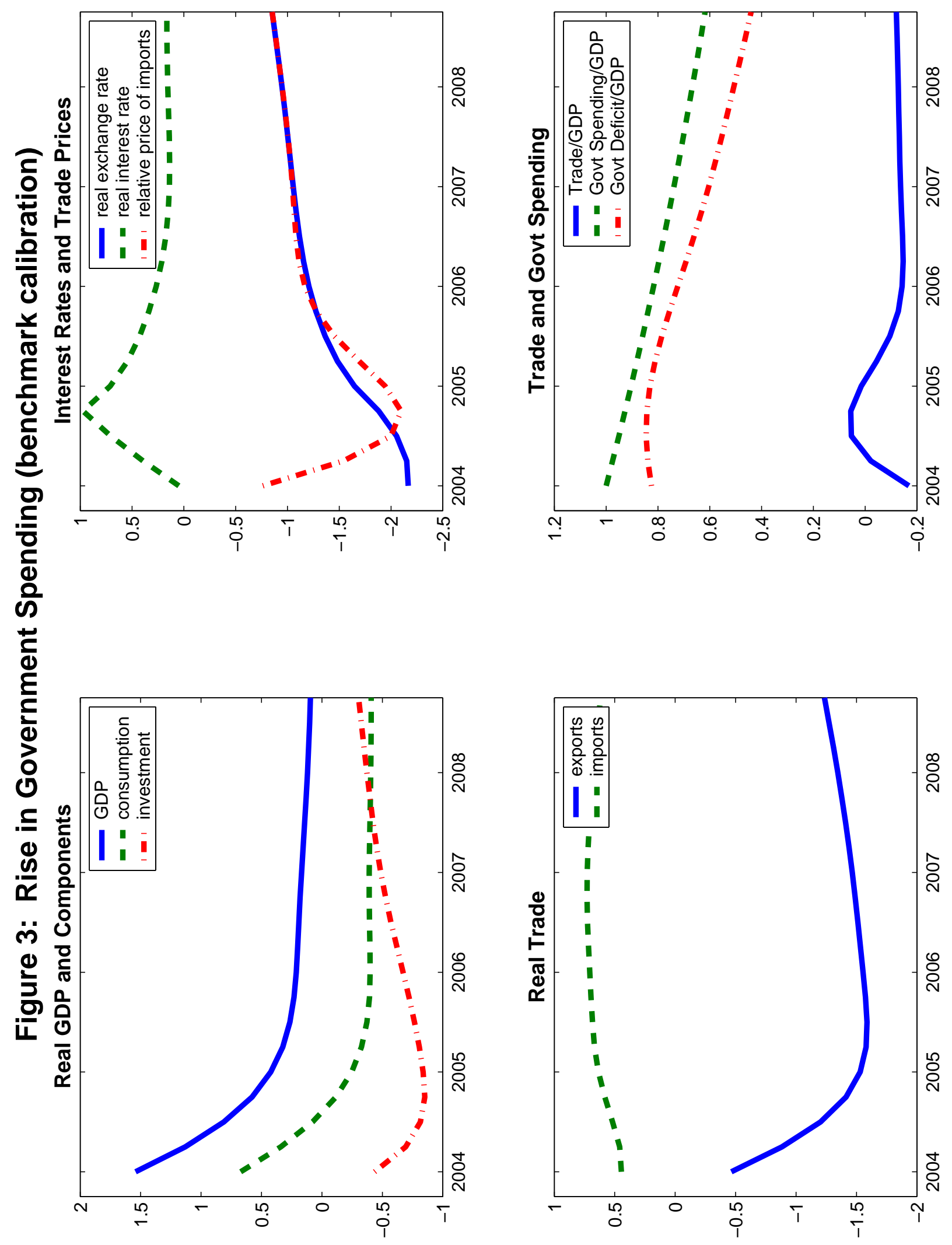

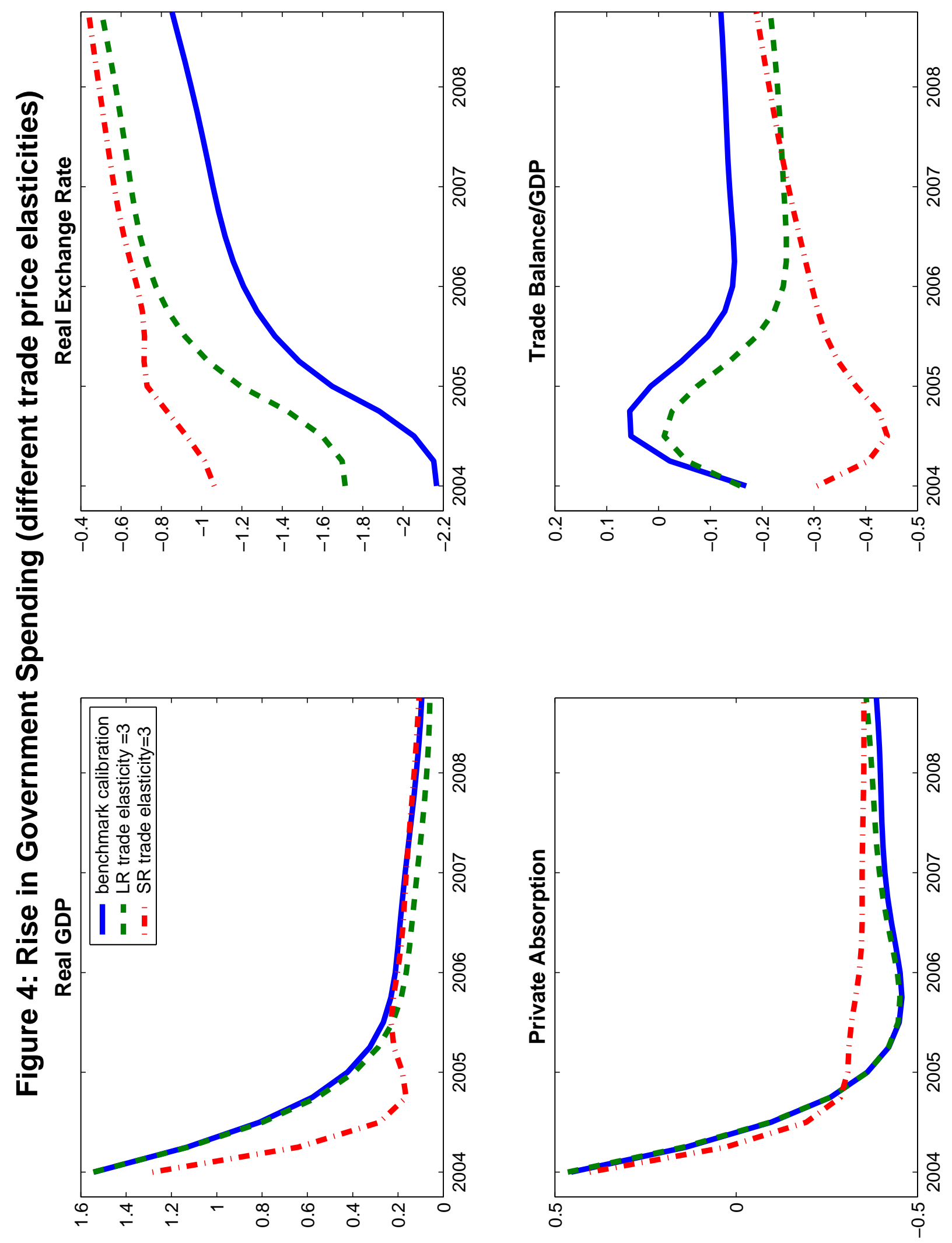

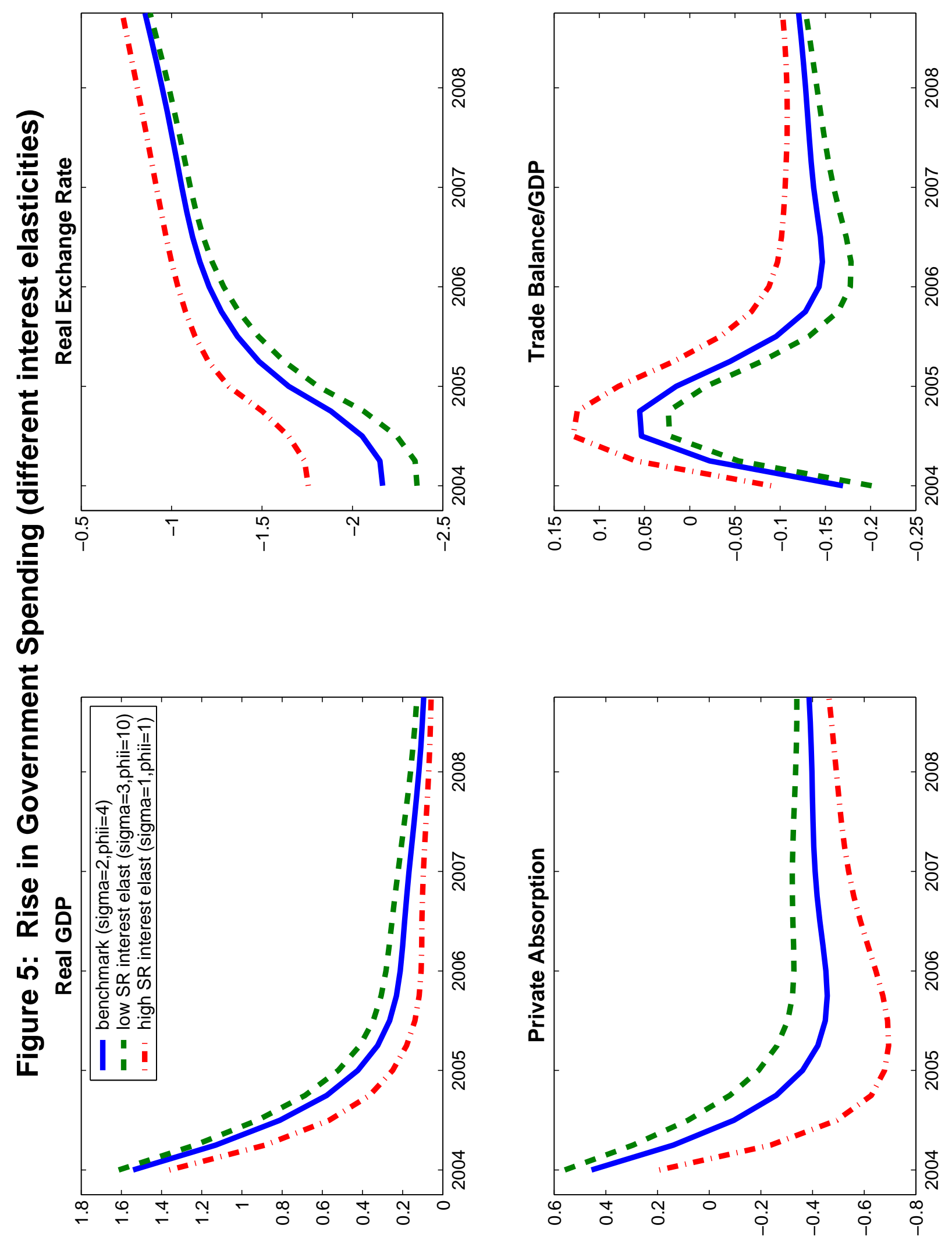

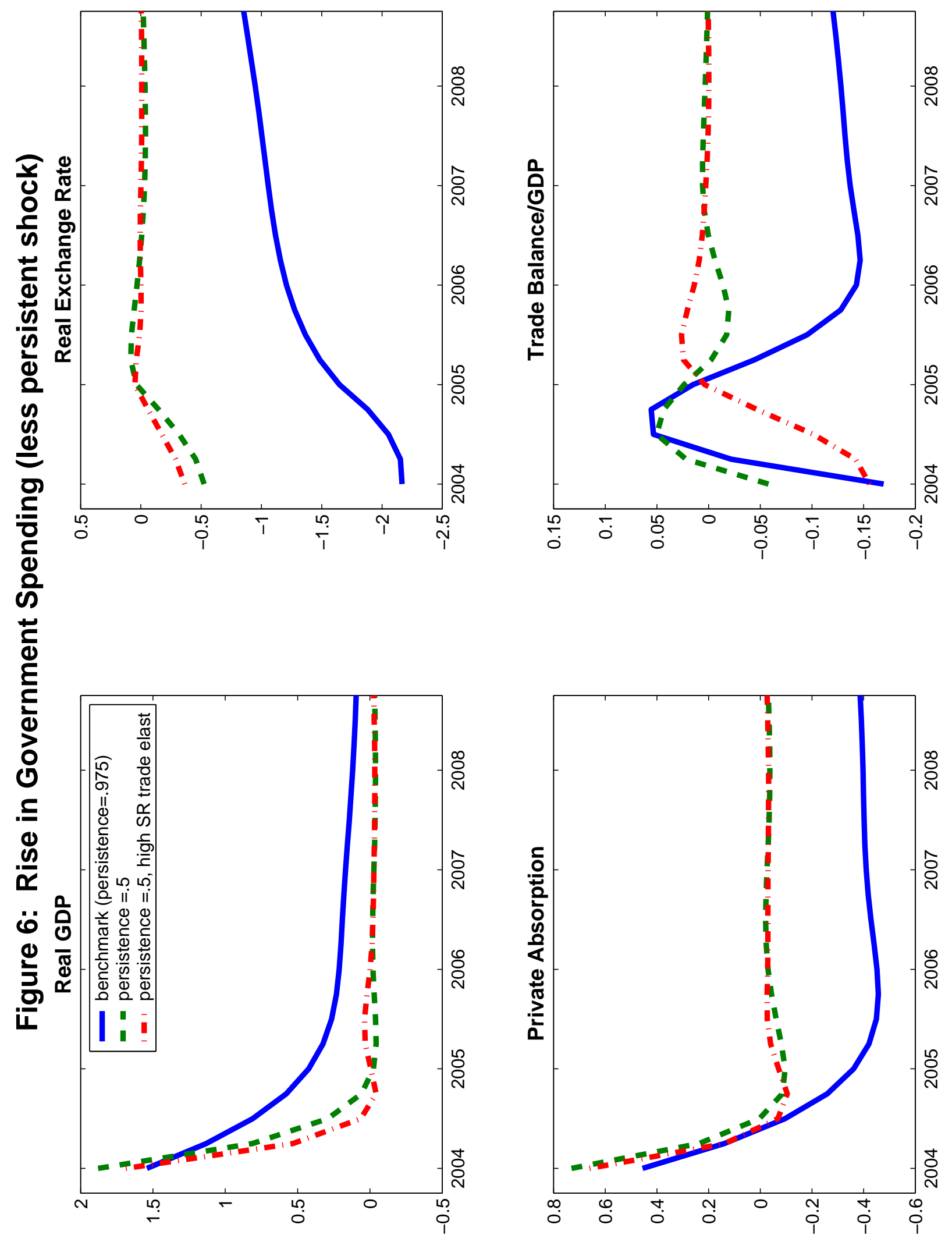

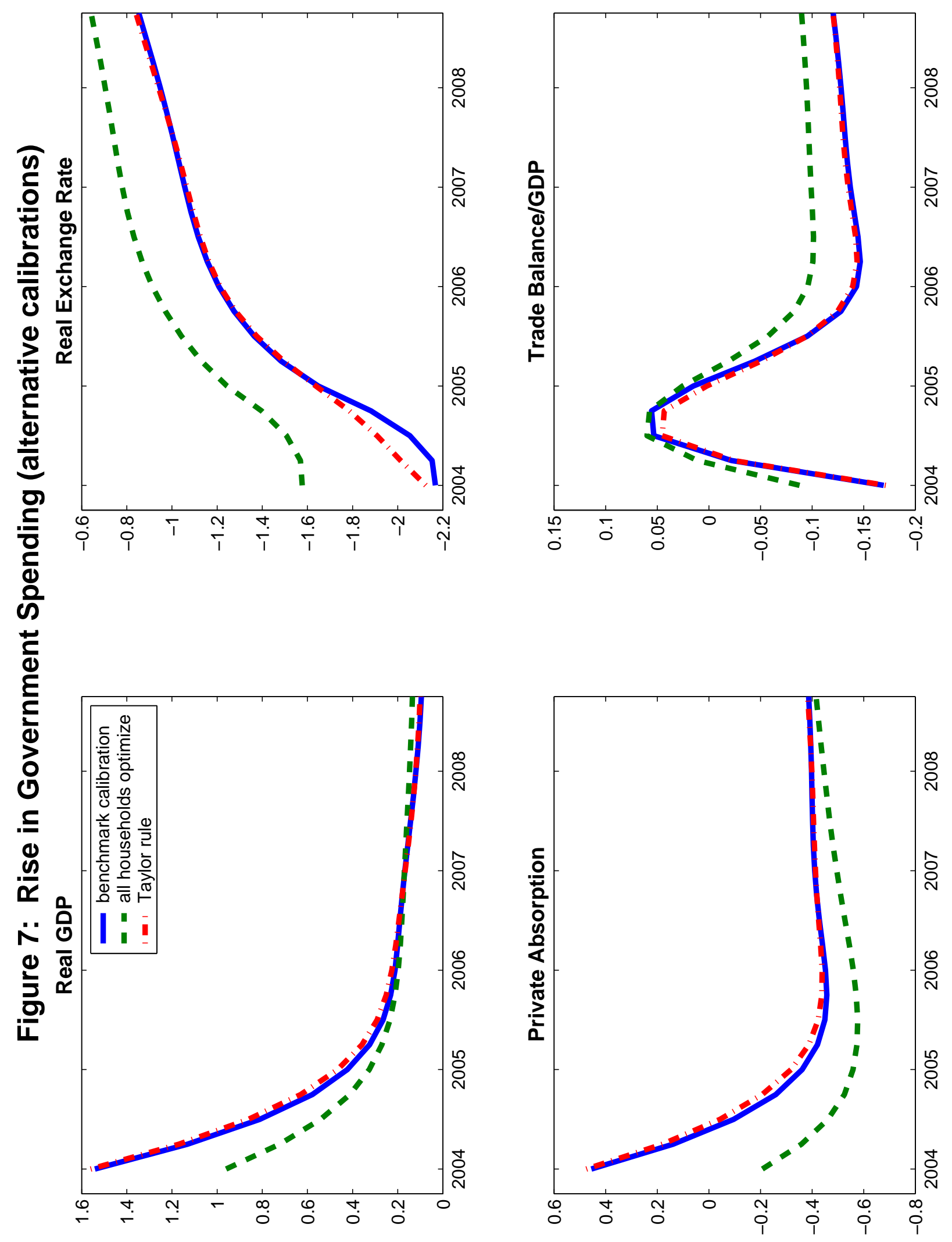

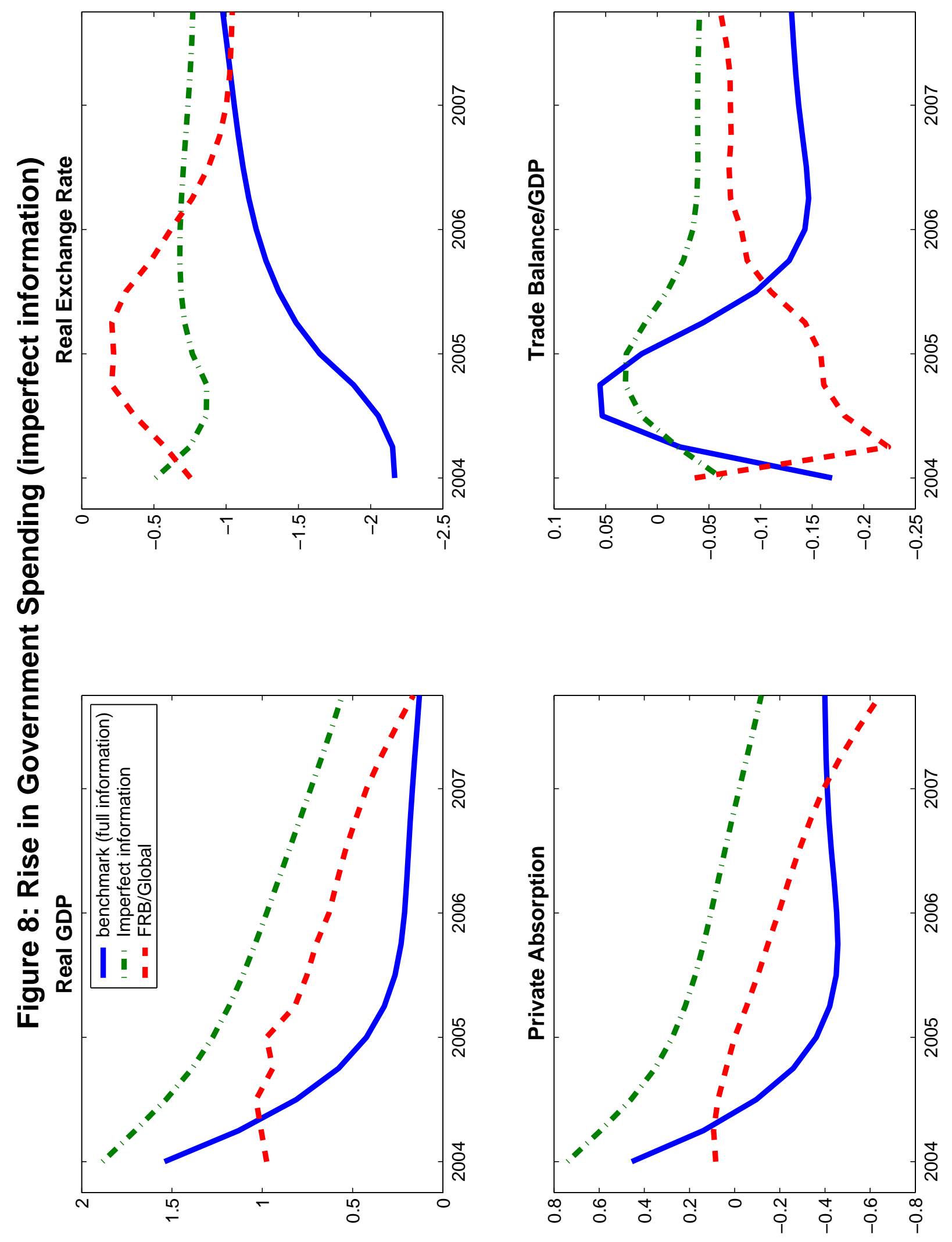

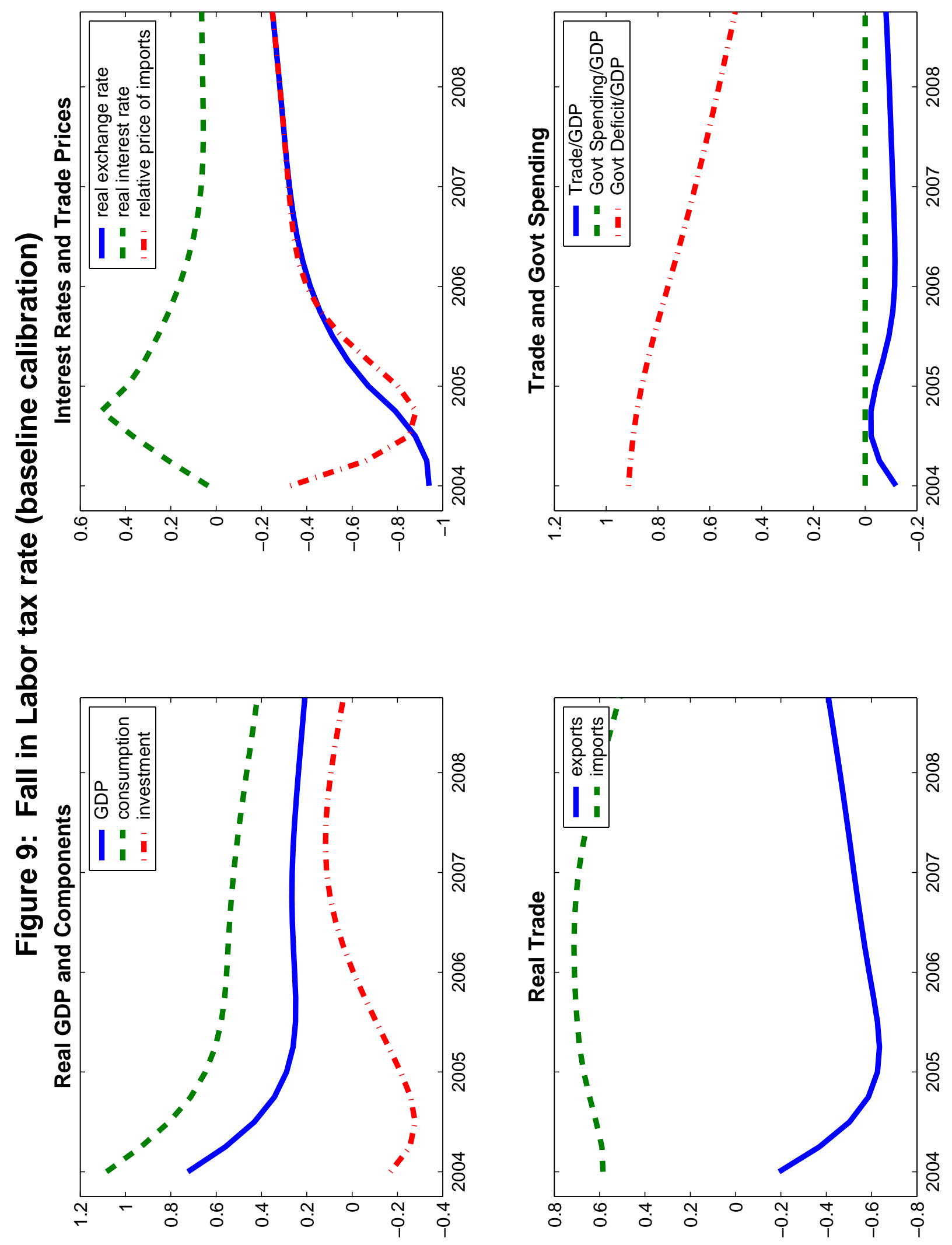

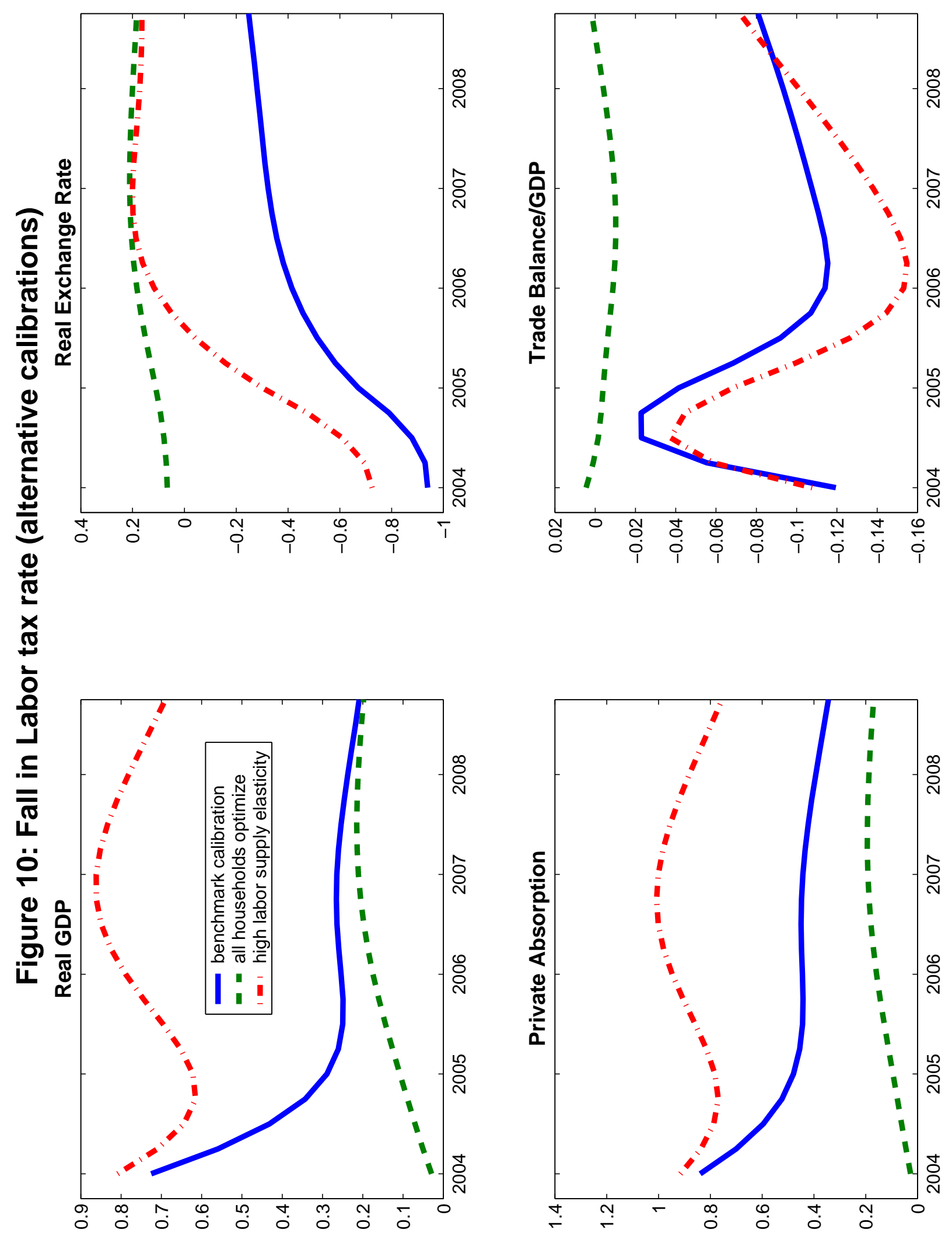